
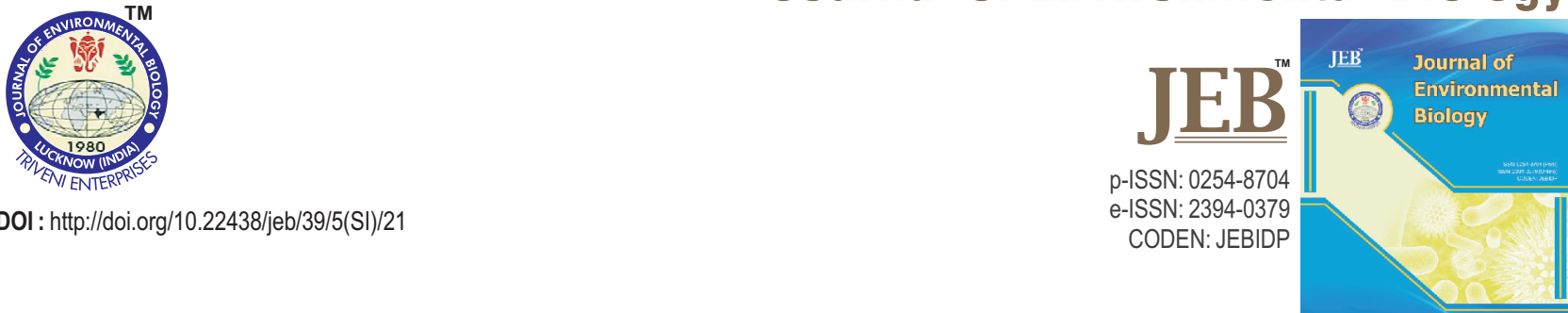

\title{
Influence of seasons, habitat sanctuaries, gears and environmental variables on the catches of hilsa shad (Tenualosa ilisha) in Bangladesh waters
}

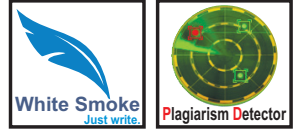

Authors Info

M. Jalilur Rahman', S. M. Nurul Amin $^{2 \star}$, M. Nahiduzzaman ${ }^{1}$, M. A. Wahab $^{1}$ and N. Romano

${ }^{1}$ ECOFISH-Bangladesh Project, WorldFish, Bangladesh \& South Asia Office, Banani, Dhaka, 1213 Bangladesh

${ }^{2}$ Laboratory of Fisheries Biology and Ecology, Department of Aquaculture, Faculty of Agriculture, Universiti Putra Malaysia, 43400 UPM, Serdang, Malaysia

${ }^{3}$ Aquaculture/Fisheries Center, University of Arkansas at Pine Bluff, 1200 North University Drive, Pine Bluff 71601, AR, USA

${ }^{*}$ Corresponding Author Email smnabd@gmail.com

Key words

CPUE variations

Dissolved oxygen

Environmental variables

Habitat sanctuaries

Hilsa shad

Publication Info

Paper received : 15.03.2017

Revised received : 20.05.2017

Re-revised received : 05.09.2017

Accepted : 28.12.2017

\section{Abstract}

Aim : Variations in catch per unit effort (CPUE) of hilsa (Tenualosa ilisha) at different habitats (sanctuaries) of Bangladesh waters were observed to understand whether CPUE variations were due to differences in habitat complexity, environmental factors or both.

Methodology : CPUE of hilsa data were collected from five different habitats in Bangladesh waters between July 2015 and June 2016. Various in-situ physico-chemical parameters were measured monthly and then examined for any relationship to CPUE.

Results : The overall mean CPUE of hilsa from the investigated areas was estimated to be $7.93 \pm 6.03 \mathrm{~kg}$ gillnet $^{-1}$ day $^{-1}$. The monthly average values of CPUE was the highest in January 2016 amounting $11.63 \pm$ $1.21 \mathrm{~kg}$ gillnet ${ }^{-1}$ day $^{-1}$ and the lowest in March 2016 amounting $3.63 \pm 0.83 \mathrm{~kg}_{\text {gillnet }}{ }^{-1}$ day $^{-1}$ with significant differences among the months $(p<0.05)$. Gillnet mesh sizes influenced the capture of hilsa with the highest $\left(9.18 \mathrm{~kg}\right.$ gillnet $^{-1}$ day $\left.^{-1}\right)$ and lowest $\left(6.05 \mathrm{~kg}_{\text {gillnet }}{ }^{-1}\right.$ day $\left.^{-1}\right)$ catch obtained from the smallest $(3.0 \mathrm{~cm})$ and largest $(11.0 \mathrm{~cm})$ mesh size, respectively. There was a lower degree of positive and negative correlation $(\mathrm{p}$ $>0.05$ ) with environmental variables and CPUE. Multiple regression analysis tests also indicated a weak overall correlation (62\%) between environmental variables and CPUE of hilsa.

Interpretation : Results likely indicate that habitat structure was more important in determining CPUE of hilsa (highest in Padma sanctuary) compared to environmental factors at the tested sites. This study emphasizes the need to conserve habitats that are often used as important fishing grounds for hilsa to ensure their adequate recruitment and ultimately sustainable management of this fishery.
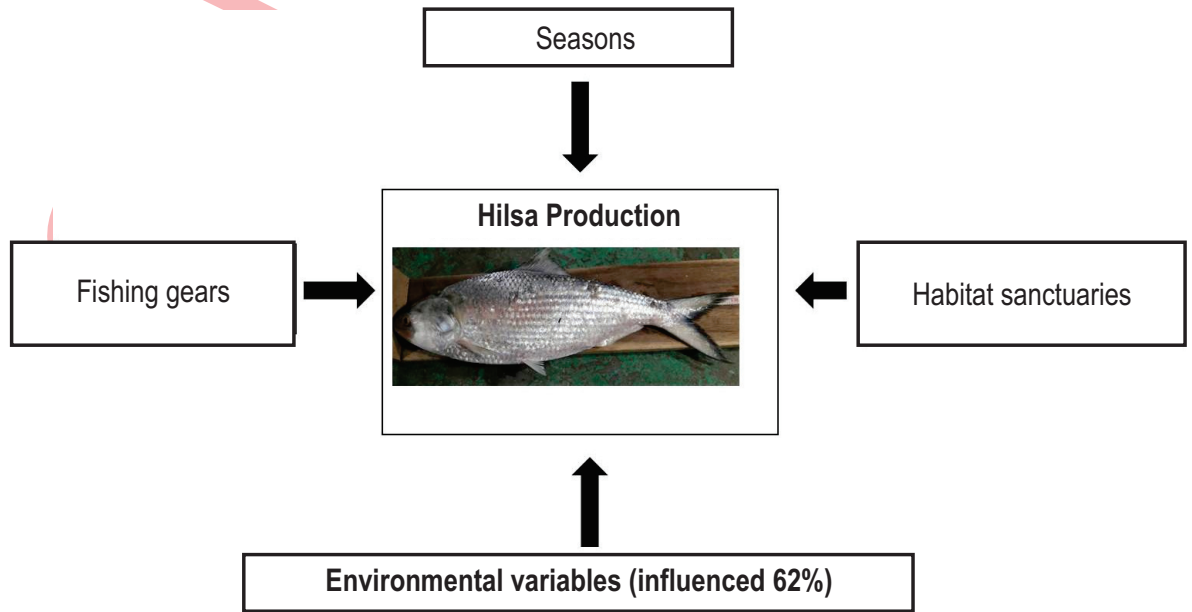


\section{Introduction}

Tenualosa ilisha (ilish, hilsa, hilsa herring or hilsa shad) belongs to sub-family Alosinae of Family Clupeidae is abundantly found in marine, estuarine and riverine aquatic systems, and is enormously important throughout the Indo-Pacific region both commercially as well as for the subsistence of improvised fisherfolks in that region. About $90 \%$ of the world's catch comes from Bangladesh, India and Myanmar at $50-60 \%, 20-25 \%$ and $5-10 \%$. For thousands of years, hilsa is part and parcel stand points of culture and tradition with people of these countries, where they prepare many delicious dishes with hilsa in religious (e.g., Eid, puja) and social (Bengali New Year even) festivals.

In Bangladesh, hilsa has been recognized as the national fish and more recently, the Directorate of Patent, Design and Trademark (DPDT) under the Ministry of Industries, Bangladesh declared the recognition of hilsa as a product of Bangladesh on 6 August 2017. Hilsa contributes to about $12 \%$ of the total fish production in Bangladesh and sales from this fish contribute approximately $1.15 \%$ of the total GDP. In addition to nearly 0.5 million people directly fishing for this species, around four to five million people are involved in selling and exporting hilsa (Siddique, 2015).

Hilsa are known to be anadromous where they migrate from the open sea to riverine systems to spawn because their eggs and juveniles cannot survive in seawater (Ahsan et al., 2014). In Bangladesh, hilsa move from the Bay of Bengal to various rivers that include Meghna, Tetulia and Andermanik Rivers to spawn (Hossain et al., 2014; Rahman et al., 2014), but require at least $10 \mathrm{~m}$ water depth for upward migration (Chowdhury et al., 2005). In these freshwater ecosystems, the larvae develop into juveniles (locally known as 'jatka'; hilsa < 25 $\mathrm{cm}$ size) until migrating into the open sea. In these river systems, both juvenile and adult hilsa are heavily fished and to protect this hilsa fishery, Government of Bangladesh has declared four areas as hilsa sanctuaries in 2005 and a fifth one in 2011. Among these five hilsa sanctuaries, four are major spawning grounds located in both coastal and freshwater areas under the 'Protection and Conservation of Fish Act-1950', and removing juveniles or adults in these areas are banned during certain times of the year.

There are several studies on population biology (Amin et al. 2000 a,b; Haldar et. al. 2001; Rahman et al., 2001; Amin et al., 2002; Haldar and Amin, 2005) that include the exploitation status (Amin et al., 2001, 2003, 2008) stock assessment and management (Amin et al. 2004); Jatka fishing and sustainability (Rahman et al., 1995; Amin et al., 2000 a; Miah et al., 2000). From these studies, it is known that the season, habitat structure and environmental parameters have an enormous effect on the distribution and abundance of hilsa. This is consistent with studies on other fish species as well. Damalas et al. (2007) revealed that eastern Mediterranean swordfish populations were predominantly influenced by spatial and temporal factors, and the main influencing environmental parameters included sea surface temperatures, lunar index and bathymetry.

In this standpoint, sustainable hilsa management requires a proper prediction of stock and their fishing; and how the seasons, habitat structure, fishing gears and environmental properties may determine the present and future stock of hilsa. Currently, however, research on hilsa shad in Bangladesh waters and their transboundaries is scarce. Thus, the present study was undertaken to determine the influence of season, habitat sanctuaries, gear and physico-chemical features on the catches of hilsa shad in Bangladesh waters.

\section{Materials and Methods}

Study sites and sampling: Catch per unit effort (CPUE) data of hilsa were collected from five different sanctuaries in Bangladesh that included, S1 (Chandpur-Laksmipur, 23.167678 $\left.90.648551^{\circ}\right)$, S2 (Bhola-Shabazpur, 22.651969 - 90.509925), S3 (Padma-Shariatpur, $23.167678^{\circ}-90.648551^{\circ}$ ), S4 (Barisal, $22.651969^{\circ}-90.509925^{\circ}$ ) and S5 (Barguna, 22.017359 , $89.955132^{\circ}$ ) during July 2015 to June 2016 (Fig.1). Hilsa were caught by four types of gillnets (Current Jal, Gulti/Pocket Jal, Chandi Jal and Zero Sutar Jal) operated by mechanized boats along the coast and all the main rivers of the country. A total of 542 gillnets were randomly selected for obtaining the CPUE data. The average length of gillnets was $1179.3 \pm 917 \mathrm{~m}$, but the overall gillnet mesh sizes varied from 3.0 to $11.0 \mathrm{~cm}$. The catch per unit effort (CPUE) was standardized by kg $1200^{-1}$ meter gillnet ${ }^{-1}$ day ${ }^{-1}$.

The water temperature $\left({ }^{\circ} \mathrm{C}\right)$, salinity, dissolved oxygen (DO), pH and conductivity were recorded from each stations in every months using a multi digital probe (YSI 650 MDS, YSI Incorporated, USA). Each water parameter was taken from a minimum of three replicates at all stations, while the monthly rainfall data were collected from the Bangladesh Meteorological Department.

Data analysis : Pearson's correlation coefficient $(r)$ was conducted to identify relationships among the environmental variables and catches (CPUE). Multiple regression analysis was conducted to determine the effect of CPUE of hilsa with environmental parameters. The formula used to determine multiple regression coefficients $\left(R^{2}\right)$ is given below:

CPUE $=0+1$ (rainfall) +2 (temp) $+3($ trans $)+4(\mathrm{DO})+5(\mathrm{pH})+6$ (Sal) +7 (Cond)

Where, 0 is the intercept (constant) and 1 to 7 are unstandardized coefficients of environmental variables. SPSS version 23 was used to perform all the above analysis. Additionally, association between sites and environmental parameters were examined with principle component analysis (PCA) using XLSTAT 2017. 


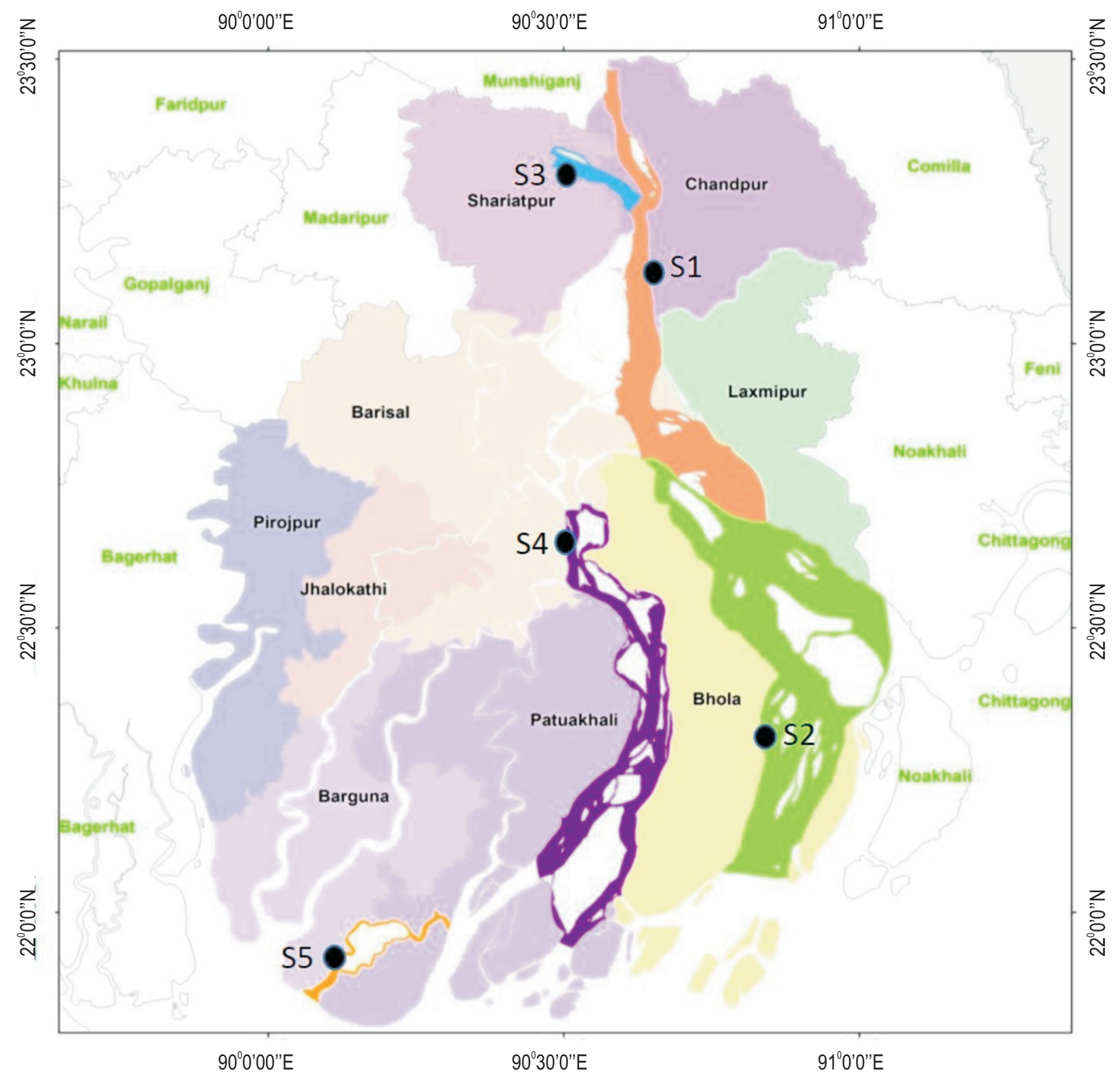

Fig. 1 : Location of different sanctuaries for hilsa conservation and collection sites (S1 -S5) of catch per unit effort data in Bangladesh waters

\section{Results and Discussion}

Environmental variables : The temporal and spatial variations of the environmental parameters are summarized in Fig. 2 (a-n). Water temperature ranged from $22.9^{\circ} \mathrm{C}$ (January 2016, at S4) to $30.8^{\circ} \mathrm{C}$ (April 2016, S5) (mean \pm SD, $28.6 \pm 2.0^{\circ} \mathrm{C}$ ), which was significantly higher during the summer season (March to October) than those of the winter (November to February) $(p<0.01)$ (Fig. 2a). Meanwhile, the mean water temperature tended to increase from station $4(27.6 \pm 0.49)$ to station $5(28.7 \pm 0.36)$, and this was statistically significant $(p<0.01)$ (Fig. $2 b)$.

The highest transparence value $(53.9 \mathrm{~cm})$ was observed during the month of February at station 3 , while the lowest value (21.9) was observed in June, at station 5 (Fig. 2c, d). The mean transparence value was found to be $32.2 \pm 1.7 \mathrm{~cm}$. Significant differences were detected for transparence among the stations $(p$ $<0.05)$ and months $(p<0.05)$. 

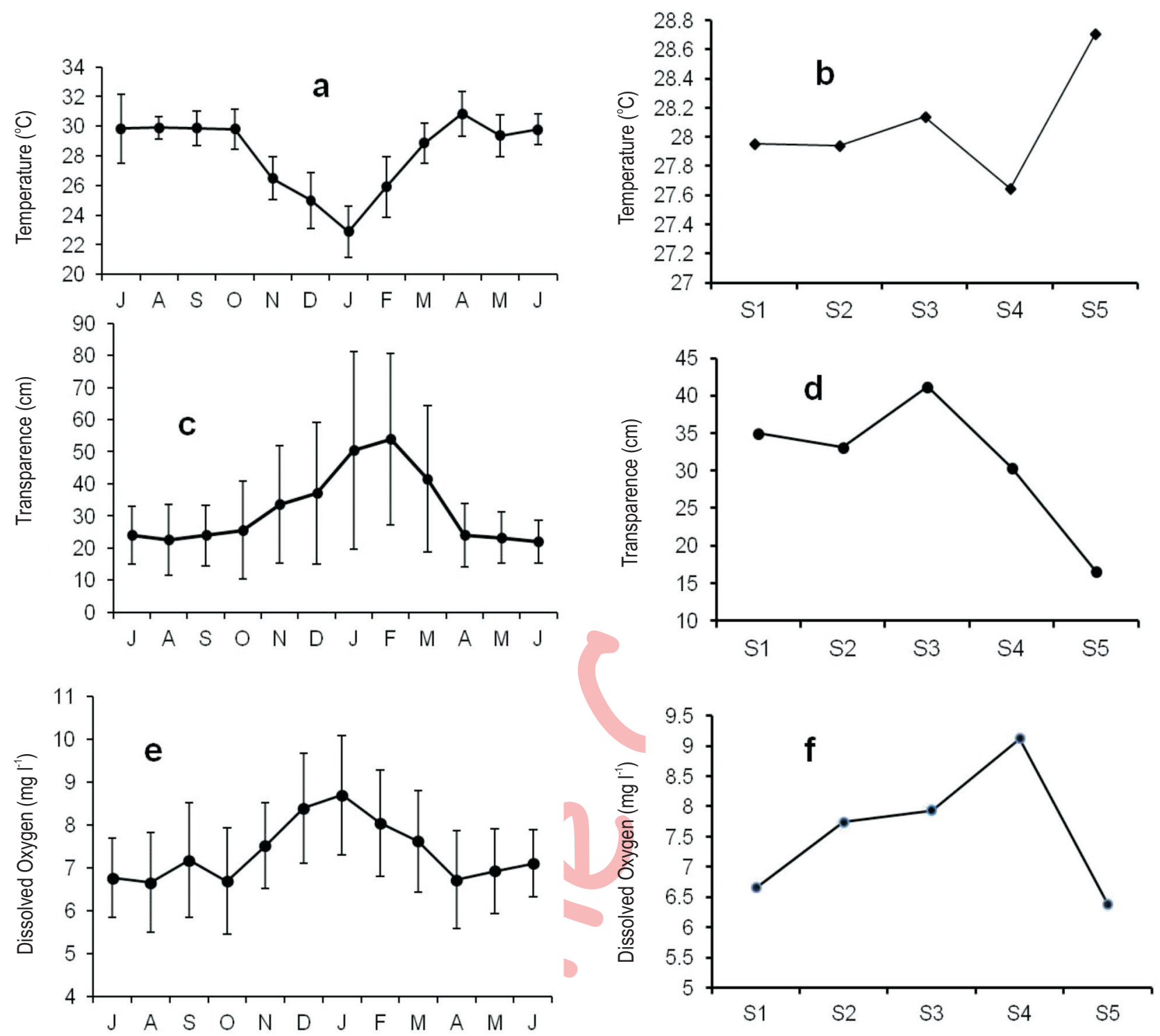

Fig. 2 (a-f) : Temporal and spatial variation of environmental variables water temperature $\left({ }^{\circ} \mathrm{C}\right)$, water transparence $(\mathrm{cm})$ dissolved oxygen $\left(\mathrm{mgl}^{-1}\right)$ in Bangladesh waters. Values are mean \pm SE

The monthly average $\mathrm{DO}$ values ranged from $6.7 \mathrm{mg} \mathrm{l}^{-1}$ (April 2015 at S5) to $8.69 \mathrm{mg} \mathrm{l}^{-1}$ (January 2016 at S4) with significant differences among the months. The DO was significantly lower in the summer season compared to the winter (Fig. 2e, f). The annual mean DO varied from $6.70 .3 \mathrm{mgl}^{-1}$ to 8.7 $0.4 \mathrm{mg} \mathrm{I}^{-1}$ in the investigated areas (Fig. 2f), and the mean DO value at station $4\left(9.1 \pm 0.3 \mathrm{mg} \mathrm{l}^{-1}\right)$ was significantly higher than those at all the other stations $(p<0.05)$ (Fig. 2f).

Salinity ranged from $0 \mathrm{ppt}$ (July to October) to $0.48 \mathrm{ppt}$ (March 2016, at S5) (Fig. 2g, h), while the highest and lowest mean salinity was recorded at station $5\left(\begin{array}{ll}0.45 & 0.11 \mathrm{ppt}\end{array}\right)$ and 3
(0.06 \pm 0.01 ppt), respectively (Fig. $2 h)$. Significant differences were observed among both the months and stations $(p<0.05)$.

The highest $\mathrm{pH}$ value (8.3) was observed during March at station 2, while the lowest $\mathrm{pH}$ (7.7) was observed in May-June at station 4 (Fig. 2i, j). The mean pH value was found to be $8.0 \pm$ 0.04 . Significant differences were detected for $\mathrm{pH}$ among both the stations $(p<0.05)$ and months $(p<0.05)$.

The highest conductivity value (487.9 $37.2 \mu \mathrm{S} \mathrm{cm}{ }^{-1}$ ) was recorded at station 2 and the lowest value $\left(186.12 \pm 8.1 \mathrm{mg} \mathrm{l}^{-1}\right)$ was found at station 1 (Fig. 2k). A higher conductivity value was 

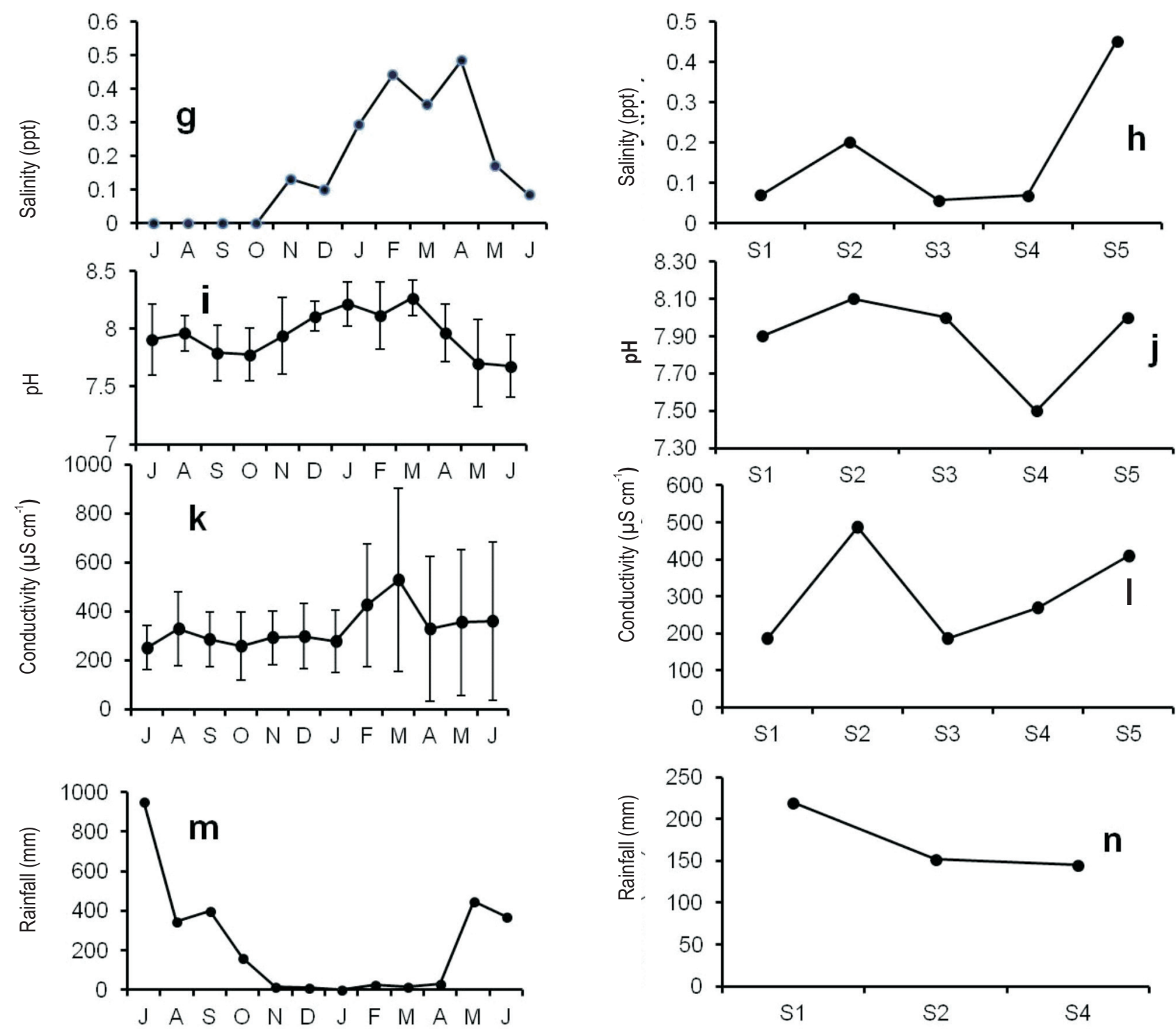

Fig. 2 (g-n): Temporal and spatial variation of environmental variables salinity (ppt), $\mathrm{pH}$, conductivity $\left(\mu \mathrm{S} \mathrm{cm}^{-1}\right)$ and rainfall (mm) in Bangladesh waters. Values are mean \pm SE

observed in June 2016 (Fig. 2l). Significant $(p<0.05)$ variations were observed for conductivity amongst different sampling stations $(p<0.05)$, as well as different months $(p<0.05)$ during the study period.

The highest rainfall $(299.30 \pm 81.25 \mathrm{~mm})$ was recorded at station 1 and the lowest $(145.0 \pm 60.3 \mathrm{~mm})$ was found at station 4 (Fig. 2m). Higher rainfall was observed in December 2015 and May - June 2016 (Fig. 2n). Significant ( $p<0.05$ ) variations were observed for rainfall among the different sampling stations $(p<$ $0.05)$, as well as different months $(p<0.05)$.

From PCA analysis, station 5 (S5) was mostly influenced by salinity and temperature fluctuation (Fig. 3). Station 2 (S2) was heavily affected by conductivity and station 1 (S1) was influenced by transparency. There was no correlation between environmental variables and station 3 and 4 (Fig. 3). Also, it revealed that DO and rainfall had less of an effect on different habitats of hilsa in Bangladesh waters.

Catch Per Unit Effort (CPUE) of hilsa : The overall mean catch per unit effort CPUE of hilsa, Tenualosa ilisha from the investigated areas was estimated to be $7.93 \pm 6.03 \mathrm{~kg} \mathrm{gillnet}^{-1}$ day $^{-1}$. The spatial variations of mean CPUE are summarized in Fig. 4a. The mean CPUE ranged from $2.86 \pm 0.25 \mathrm{~kg} \mathrm{gillnet}^{-1}$ 
Table 1: Correlation coefficient $₫$ between CPUE of hilsa and environmental variables in the Bangladesh waters

\begin{tabular}{|c|c|c|c|c|c|c|c|}
\hline Catch & Rainfall & Temp. & Transp. & DO & $\mathrm{pH}$ & Salinity & Cond. \\
\hline CPUE (kg gillnet ${ }^{-1}$ day $^{-1}$ ) & -0.054 & -0.293 & 0.208 & 0.236 & -0.132 & -0.284 & -0.321 \\
\hline
\end{tabular}

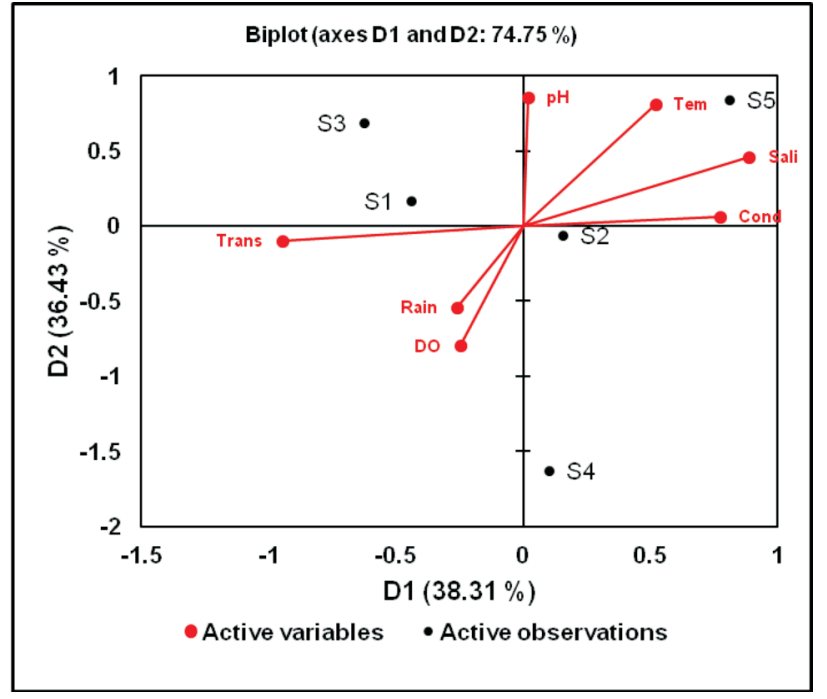

Fig. 3 : Principle component analysis ordination of spatial (S1-S5) variation in environmental variables (dots)

day $^{-1}$ (Barisal) to $13.09 \pm 0.99 \mathrm{~kg}$ gillnet $^{-1}$ day $^{-1}$ (PadmaShariatpur sanctuary) and the mean CPUE at PadmaShariatpur station was significantly higher than those at all other stations $(p<0.05)$. Changes in the mean CPUE of hilsa for each month are presented in Fig. 4b. The monthly average values of CPUE was the highest in January 2016 amounting $11.63 \pm 1.21 \mathrm{~kg}$ gillnet $^{-1}$ day $^{-1}$ and the lowest in March 2016 amounting $3.63 \pm 0.83 \mathrm{~kg}$ gillnet $^{-1}$ day $^{-1}$ with significant differences among the months $(p<0.05)$. The mean CPUE of hilsa increased from July and reached a peak in SeptemberOctober, January-February and May-June. The CPUE values remained low in July-August, November-December and MarchApril (Fig. 4b). This indicates that T. ilisha migrates continuously throughout the year to the coast and all the main rivers of the country. However, peak migrations occurred in SeptemberOctober and continued at two-month intervals (Fig.4b). Among the four type of gillnets, Gulti/Pocket Jala was the most efficient gear as it showed the highest catch (11.86 $\left.\mathrm{kg}_{\text {gillnet }}{ }^{-1} \mathrm{day}^{-1}\right)$, while the less efficient gear was Zero Sutar Jal leading to the lowest catch (2.94 kg gillnet ${ }^{-1}$ day $\left.^{-1}\right)$ (Fig. 4c). It was observed that gill net mesh sizes influenced the capture of hilsa. The highest catch $\left(9.18 \mathrm{~kg}_{\text {gillnet }}{ }^{-1} \mathrm{day}^{-1}\right)$ was found using gillnet of mesh size $3.00 \mathrm{~cm}$, while the lowest catch $\left(6.05 \mathrm{~kg} \mathrm{gillnet}^{-1} \mathrm{day}^{-1}\right)$ was observed using gillnet of mesh size $11.00 \mathrm{~cm}$ (Fig. 4d).
Relationship between CPUE of hilsa and environmental variables : Catch per unit effort (CPUE) of hilsa had correlations (positive or negative) with the measured environmental parameters, which are presented in Table 1. None of the environmental variables was significantly $(p>0.05)$ correlated with CPUE. However, to obtain a specific relationship with these parameters and CPUE, a multiple regression model equation was established. This showed that a combination of seven environmental variables (rainfall, temperature, transparence, dissolved oxygen, $\mathrm{pH}$, salinity and conductivity) predicted CPUE of hilsa in Bangladesh waters at $62 \%(p>0.05)$ and the findings are presented in Table 2. Based on the standardized coefficients (Beta), the best predictor of CPUE of hilsa was transparence (Beta $=1.84)$, which was higher than other variables (Table 2). The multiple regression model equation that predicted CPUE of hilsa is as follows:

CPUE $=30.683-0.003$ Rain +1.568 Tem +0.477 Trans +2.405 DO-11.338 pH - 10.770 Sal -0.022 Cond $\left(R^{2}=0.62, p>0.05\right)$.

Detail explanation of the above model is given below:

- with every $1 \mathrm{~mm}$ increase of rainfall, there was $0.003 \mathrm{~kg}$ decrease of hilsa in CPUE

- with every $1^{0} \mathrm{C}$ increase of temperature, there was $1.568 \mathrm{~kg}$ increase of hilsa in CPUE

- with every $1 \mathrm{~cm}$ increase of transparence, there was $0.477 \mathrm{~kg}$ increase of hilsa in CPUE

- with every $1 \mathrm{mg} \mathrm{l}^{-1}$ increase of DO, there was $2.40 \mathrm{~kg}$ increase of hilsa in CPUE

- with every 1 unit increase of $\mathrm{pH}$, there was $11.338 \mathrm{~kg}$ decrease of hilsa in CPUE

- with every $1 \mathrm{ppt}$ increase of salinity, there was $10.77 \mathrm{~kg}$ decrease of hilsa in CPUE

- with every $1 \mu \mathrm{S} \mathrm{cm}^{-1}$ increase of conductivity, there was $0.022 \mathrm{~kg}$ decrease of hilsa in CPUE.

Suitable aquatic environmental parameters can greatly influence the assemblages of biota in aquatic ecosystems and, in particular, estuarine environments show broad fluctuations in physico-chemical properties owing to variable but continuous mixing of marine and freshwater (George et al., 2012). Several studies showed that some of these physico-chemical 

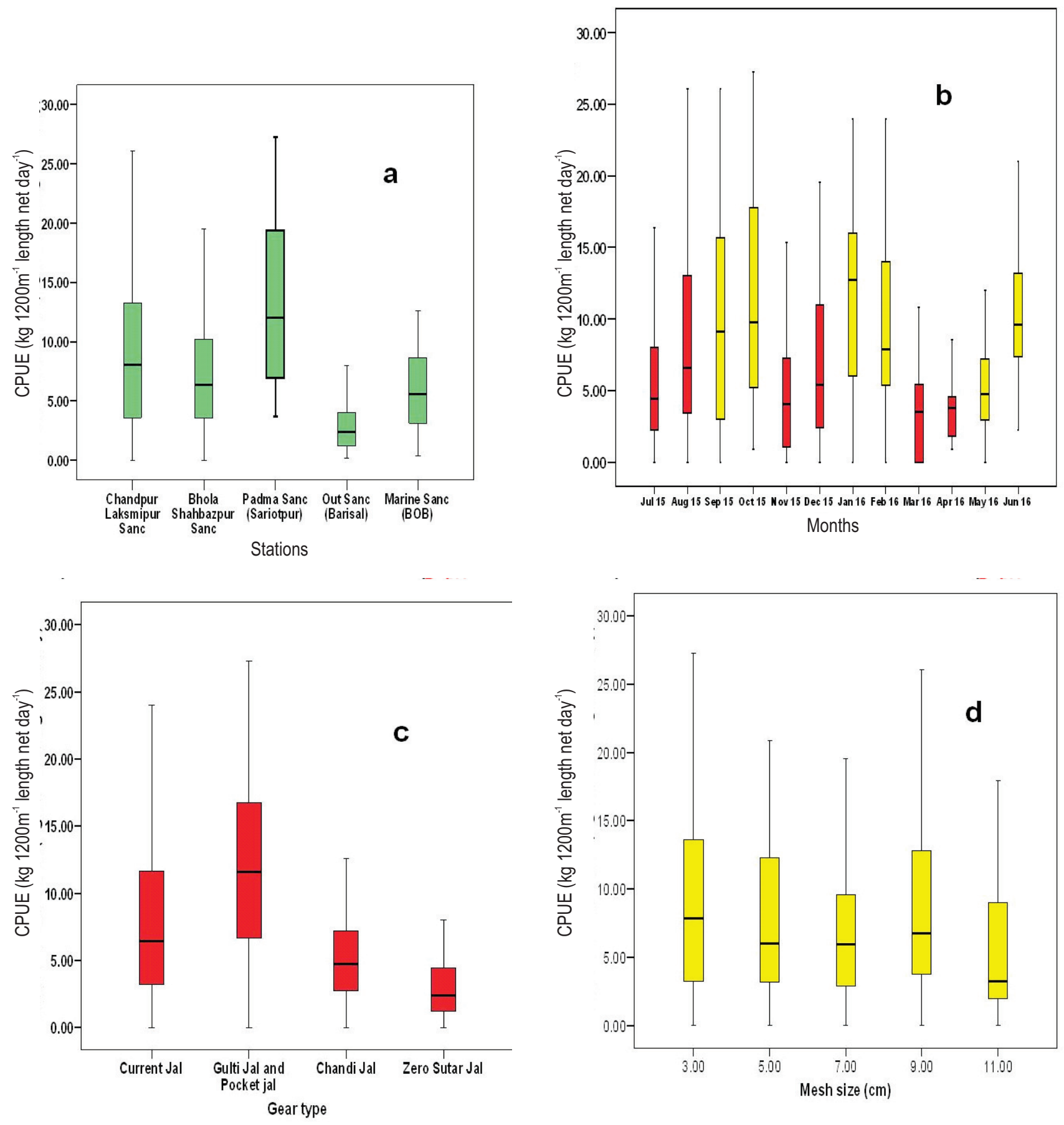

Fig. 4 (a-d): Catch per unit effort (CPUE) of hilsa, Tenualosa ilisha based on (a) stations (b) months (c) gear and (d) mesh size in Bangladesh waters

characteristics can influence fish abundance, migration, breeding and spawning, while the subsequent survival of larvae are affected by elevation, water depth, river width, river slope, current velocity, transparency, water temperature, dissolved oxygen, $\mathrm{pH}$, conductivity and total dissolved solids (Faradonbe and Eagderi, 2015; Vega-Cendejas et al., 2013; Rashleigh, 2004; Maes et al.,
2004; Kathiresan and Bingham, 2001; Whitfield, 1999). In the present study, temperature remained relatively stable throughout the months, with the minimum temperature of $22.9^{\circ} \mathrm{C}$ occurred in January 2016 and maximum $30.8^{\circ} \mathrm{C}$ in April, which was higher during the summer season (March to October) and lower in winter (November to February). Similar results were also reported by 
Table 2: Standard coefficient of (Beta) of different models for predicting CPUE of hilsa in Bangladesh using environmental variables

\begin{tabular}{|c|c|c|c|c|c|c|c|c|}
\hline \multirow{2}{*}{\multicolumn{2}{|c|}{ Model }} & \multicolumn{2}{|c|}{$\begin{array}{c}\text { Unstandardized } \\
\text { Coefficients }\end{array}$} & \multirow{2}{*}{$\begin{array}{c}\begin{array}{c}\text { Standardized } \\
\text { Coefficients }\end{array} \\
\text { Beta }\end{array}$} & \multirow[b]{2}{*}{$t$} & \multirow[b]{2}{*}{ Sig } & \multicolumn{2}{|c|}{$95 \%$ Confidence Interval for B } \\
\hline & & B & Std.Error & & & & Lower Bound & Upper Bound \\
\hline \multirow[t]{2}{*}{1} & (Constant) & 7.718 & 1.172 & & 6.584 & .000 & 5.106 & 10.330 \\
\hline & Annual rainfall & -0.01 & .003 & -054 & -170 & .869 & -008 & .007 \\
\hline \multirow[t]{3}{*}{2} & (Constant) & 19.458 & 12.023 & & 1.618 & .140 & -7.739 & 46.656 \\
\hline & Annual rainfall & .001 & .004 & .136 & .368 & .721 & -.007 & .010 \\
\hline & Temperature $^{\circ} \mathrm{C}$ & -432 & .441 & -.364 & -.981 & .352 & -1.429 & .564 \\
\hline \multirow[t]{4}{*}{3} & (Constant) & 20.958 & 24.483 & & .856 & .417 & -35.501 & 77.416 \\
\hline & Annual rainfall & .001 & .004 & .126 & .300 & .772 & -.009 & .011 \\
\hline & Temperature $^{\circ} \mathrm{C}$ & -471 & .717 & -.397 & -.659 & .528 & -2.119 & 1.177 \\
\hline & Transperency $(\mathrm{cm})$ & -012 & .167 & -.046 & -.072 & .945 & -.396 & .372 \\
\hline \multirow[t]{5}{*}{4} & (Constant) & 38.256 & 70.566 & & .542 & .605 & -128.606 & 205.117 \\
\hline & Annual rainfall & .001 & .005 & .110 & .243 & .815 & -.010 & .012 \\
\hline & Temperature $^{\circ} \mathrm{C}$ & -748 & 1.297 & -.630 & -.577 & .582 & -3.816 & 2.319 \\
\hline & Transperency $(\mathrm{cm})$ & .007 & .192 & .028 & .038 & .971 & -.446 & .461 \\
\hline & Dissolved Oxygen $\left(\mathrm{mg} \mathrm{l}^{-1}\right)$ & -1.366 & 5.178 & -.321 & -.264 & .800 & -13.609 & 10.878 \\
\hline \multirow[t]{6}{*}{5} & (Constant) & 113.695 & 86.109 & & 1.320 & .235 & -97.006 & 324.395 \\
\hline & Annual rainfall & .000 & .004 & .040 & .093 & .929 & -.010 & .011 \\
\hline & Temperature $^{\circ} \mathrm{C}$ & -401 & 1.247 & -.337 & -.321 & .759 & -3.452 & 2.651 \\
\hline & Transperency $(\mathrm{cm})$ & 175 & .218 & .672 & .803 & .453 & -.358 & .707 \\
\hline & Dissolved Oxygen $\left(\mathrm{mgl}^{-1}\right)$ & -.356 & 4.930 & -.084 & -.072 & .945 & -12.419 & 11.706 \\
\hline & $\mathrm{Ph}$ & -12.303 & 8.934 & -.805 & -1.377 & .218 & -34.163 & 9.557 \\
\hline \multirow[t]{7}{*}{6} & (Constant) & 84.934 & 83.332 & 8 & 1.019 & .355 & -129.277 & 299.146 \\
\hline & Annual rainfall & -.002 & .005 & -.225 & -.507 & .634 & -.014 & .010 \\
\hline & Temperature $^{\circ} \mathrm{C}$ & .254 & 1.263 & .214 & .201 & .849 & -2.992 & 3.500 \\
\hline & Transperency $(\mathrm{cm})$ & .337 & .236 & 1.297 & 1.428 & .213 & -.270 & .944 \\
\hline & Dissolved Oxygen $\left(\mathrm{mg} \mathrm{l}^{-1}\right)$ & -.157 & 4.617 & -.037 & -.034 & .974 & -12.025 & 11.710 \\
\hline & $\mathrm{Ph}$ & -.11 .515 & 8.382 & -.753 & -1.374 & .228 & -33.063 & 10.032 \\
\hline & Salinity (ppt) & -11.486 & 8.449 & -.691 & -1.359 & .232 & -33.206 & 10.234 \\
\hline \multirow[t]{8}{*}{7} & (Constant) & 30.683 & 96.111 & 8 & .319 & .766 & -236.163 & 297.528 \\
\hline & Annual rainfall & -.003 & .005 & -.307 & -.691 & .528 & -.016 & .010 \\
\hline & Temperature $^{\circ} \mathrm{C}$ & 1.568 & 1.738 & 1.320 & .902 & .418 & -3.258 & 6.394 \\
\hline & Transperency $(\mathrm{cm})$ & .477 & .266 & 1.836 & 1.794 & .147 & -2.61 & 1.215 \\
\hline & Dissolved Oxygen $\left(\mathrm{mg} \mathrm{l}^{-1}\right)$ & 2.405 & 5.122 & .566 & .469 & .663 & -11.817 & 16.627 \\
\hline & $\mathrm{Ph}$ & -11.338 & 8.246 & -.742 & -1.375 & .241 & -34.234 & 11.557 \\
\hline & Salinity (ppt) & -10.770 & 8.337 & -.648 & -1.292 & .266 & -33.918 & 12.377 \\
\hline & Conductivity $\left(\mu \mathrm{S} \mathrm{cm}^{-1}\right)$ & -.022 & .021 & -.596 & -1.081 & .341 & -.080 & .035 \\
\hline
\end{tabular}

a. Dependent variable : CPUE $\left(\mathrm{kg} 1200 \mathrm{~m}^{-1}\right.$ length net day $\left.^{-1}\right)$

Sharif et al. (2017a, b) from lower Meghna River and its estuary. Water transparency showed differences among hilsa habitats, which ranged from $21.9 \mathrm{~cm}$ to $53.9 \mathrm{~cm}$, and seasonal changes in water transparency was also observed by Sharif et al. (2017a) from the Meghna estuaries of Bangladesh. They reported the highest $(65 \mathrm{~cm})$ transparency at Bhola in post monsoon and lowest $(4 \mathrm{~cm})$ at Sandwip in monsoon. Ahsan et al. (2014) revealed that water transparency of the river water was less turbid in Rajshahi and coastal areas, but was highly turbid in Chandpur area, i.e., the upper Meghna area.

The dissolved oxygen showed significant differences among the months, which was highest and lowest during summer and winter season. Nevertheless, the DO was suitable for aquatic biota (U.S. EPA 2000) with the annual mean fluctuating from $6.70 .3 \mathrm{mg} \mathrm{l}^{-1}$ to $8.70 .4 \mathrm{mg} \mathrm{l}^{-1}$ in the investigated areas. Ahsan et al. (2014) reported higher DO during April and May, and the range was moderate at $4.0-7.6 \mathrm{mgl}^{-1}$. They also observed that the DO ranged from 5.2 to $7.4 \mathrm{mg} \mathrm{l}^{-1}$ in upper freshwater zone, which was suitable for migration and nursery of hilsa owing to high productivity of the riverine ecosystem.

The salinity, $\mathrm{pH}$ and conductivity differed by months and stations. In the case of salinity, however, this had a minimal fluctuation from 0 to $0.48 \mathrm{ppt}$. The minimum $\mathrm{pH}(7.7)$ was found during May-June at Barisal sanctuary (S4), while the highest (8.3) 
was observed in March at Bhola-Shabazpur sanctuary (S2) during the study period. The conductivity varied from $186.12 \pm 8.1$ $\mathrm{mg} \mathrm{I}^{-1}$ at the Chandpur sanctuary to $487.9 \pm 37.2 \mu \mathrm{S} \mathrm{cm}^{-1}$ at the Meghna sanctuary. Sharif et al. (2017a) showed that the pH varied from 6.4 to 7.0 at monsoon and post monsoon from the Meghna estuaries of Bangladesh. Ahsan et al. (2014) reported threshold values of $\mathrm{pH} 7.70-8.30$ and $7.9-8.40$ for breeding and nursery activities, respectively, while the salinity was $<0.1 \mathrm{ppt}$. Montana et al. (2011) found the pH level of 6.5 in 2003 summer to 7.5 in summer, monsoon and winter at the River Ganges at Bhagalpur, India. This shower slightly increasing trend and 2006 and $2007 \mathrm{pH}$ level from 7.3 to 7.5 was quite stable. In the present study, the $\mathrm{pH}$ tended to be higher than those reported by Montana et al. (2011), which was suitable for breeding and nursery of hilsa. Overall, the environmental variables in the present study was found to be consistent with those reported by several researchers (Sharif et al., 2017a, b; Montana et al., 2011; Ahsan et al., 2014).

Gillnets are widely used fishing gear throughout the world (Jefferson and Curry, 1994), including in Bangladesh (Kibria and Ahmed, 2005). In this study, four different types gillnets were used to catch hilsa and it was found that Gulti/Pocket gillnets led to the highest catch at $11.86 \mathrm{~kg}$ gillnet ${ }^{-1} \mathrm{day}^{-1}$, whereas the least efficient gear was the Zero Sutar gillnet with a catch of $2.94 \mathrm{~kg}_{\text {gillnet }}{ }^{-1} \mathrm{day}^{-1}$. Moreover, the gillnet mesh size also influenced the amount of caught hilsa, with the highest coming from a mesh size of $3.0 \mathrm{~cm}$ (at $9.18 \mathrm{~kg}$ gillnet ${ }^{-1} \mathrm{day}^{-1}$ ) compared to a mesh size of $11.0 \mathrm{~cm}$ (at $6.05 \mathrm{~kg}$ gillnet $\left.{ }^{-1} \mathrm{day}^{-1}\right)$. Amin et al. (2008) reported a mean CPUE of $45.7 \mathrm{~kg} / \mathrm{boat} / \mathrm{day}$ for adult hilsa when using gill nets sizes that ranged from 10.6 to $19.1 \mathrm{~cm}$ during the peak period (SeptemberOctober) in the Ramgoti area of Meghna River, Bangladesh. On the other hand, Pramanik et al. (2017) showed that smaller gill nets of 5.5 and $6.5 \mathrm{~cm}$ led to a higher percentage of caught hilsa at 39.10 and $38.78 \%$, respectively, compared to a bigger gill net mesh size of $7.5 \mathrm{~cm}$ at $22.12 \%$.

According to Mia (2015), hilsa migrates from the Bay of Bengal to upstream rivers i.e., the Ganges (Padma), Meghna and other rivers of Bangladesh for breeding. In these habitats, the larvae and juveniles grow in the fresh water before returning back to the Bay of Bengal. According to Islam (1989), the spawning of hilsa takes place most of the year, but peak spawning occurs in October-November, while the lowest occurs in June-July and February-March. Therefore, migrations are undertaken mostly to spawn (Islam, 1989). It was observed that the mean CPUE of hilsa increased from July and reached a peak in SeptemberOctober, January-February and May-June. The CPUE values remained low in July-August, November-December and MarchApril (Fig.4b). This therefore indicates that hilsa migrates continuously throughout the year in the coast and all the main rivers of the country. The present study also showed that the Padma-Sariotpur sanctuary had a higher CPUE, but was more or less similar to the other research stations. The lowest CPUE of hilsa was observed at station 4 (Barisal) which is out of sanctuary that revealed sanctuary played important role in hilsa fishery including production.

The regression coefficient $\left(R^{2}\right)$ of 0.62 with the seven measured environmental variables indicates that it can change $62 \%$ of hilsa production, although this was not significant. Therefore, other unknown factors were responsible for remaining $38 \%$ of hilsa production. Among the seven parameters, increasing temperature, transparency and free dissolved oxygen increased hilsa production and conversely, increasing rainfall, $\mathrm{pH}$, salinity and conductivity decreased hilsa productivity. This indicate that habitat structure was more important in determining CPUE of hilsa (highest in Padma sanctuary) compared to environmental factors at the tested sites. This study emphasizes the need to conserve habitats that are often used as important fishing grounds for hilsa to ensure their adequate recruitment, and ultimately the sustainable management of this fishery.

\section{Acknowledgments}

The authors acknowledge the financial support provided by USAID through the Enhanced Coastal Fisheries in Bangladesh (ECOFISH) project, jointly led by the Department of Fisheries (DoF), Bangladesh and the CGIAR WorldFish Center in Bangladesh. Thanks to the Research Associates and Research Assistance of the ECOFISH Project for their efforts in collecting field data.

\section{References}

Ahsan, D. A., M.N. Naser, U. Bhoumik, S. Hazra and S.B. Bhattacharya: Migration, spawning patterns and conservation of Hilsa shad (Tenualosa ilisha) in Bangladesh and India. New Delhi, Academic Foundation (2014).

Allison, E. H., A.L. Perry, M. Badjeck, W.N. Adger, K. Brown and D. Conway: Vulnerability of national economics to the impacts of climate change on fisheries. Fish and Fisheries, 10, 173-196 (2009).

Amin, S.M.N., M.A. Rahman, G.C. Haldar and M.A. Mazid: Some population dynamics aspects of Tenualosa ilisha from Khulna offshore region of Bangladesh. J. Nati. Oceanograp. Maritime Inst., 17, 9-17 (2000a).

Amin, S.M.N., M.A. Rahman, G.C. Haldar, M.A. Mazid and D. A. Milton: Population dynamics and stock assessment of Hilsa shad, Tenualosa ilisha in Bangladesh. Asian Fisheries Sci., 15, 123-128 (2002).

Amin, S.M.N., M.A. Rahman, G.C. Haldar, M.A. Mazid and D.A. Milton: Catch per unit effort, exploitation level and production of Hilsa shad in Bangladesh waters. Asian Fisheries Sci., 2,175-187 (2008).

Amin, S.M.N., M.A. Rahman, G.C. Haldar, M.A. Mazid and M. Sinha: Exploitation of hilsa (Tenualosa ilisha) juveniles and adults in Bangladesh - A comparative study. J. Nati. Oceanograp. Maritime Inst., 20, 15-23 (2003).

Amin, S.M.N., M.A. Rahman, G.C. Haldar, M.A. Mazid, D.A. Milton and S.J.M. Blaber: Stock assessment and management of Tenualosa ilisha in Bangladesh. Asian Fisheries Science, 17, 50-59 (2004).

Amin, S.M.N., M.A. Rahman, G.C. Haldar, S. Nahar, S. Dewan and M.A. Mazid: Population dynamics of Jatka (Juvenile Hilsa) in the 
Meghna River, Bangladesh. Asian Fisheries Sci., 13,383-389 (2000b).

Amin, S.M.N., M.A. Rahman, G.C. Hilda and M.A. Mazid: Studies on age and growth and exploitation level of Tenualosa ilisha in the coastal region of Chittagong, Bangladesh. J. Inland Fisher. Soc. India, 33, 1-5 (2001).

Chowdhury, M. S. M., G. Khan, A. Nishat, R. Rahman and R. Amin: Assessment of the Minimum Environmental Flow in Bakkhali River, Cox's Bazar. IUCN/UNEP Report, No. 2 (2005).

Damalas, D., P. Megalofonou and M. Apostolopoulou: Environmental, spatial, temporal and operational effects on swordfish (Xiphias gladius) catch rates of eastern Mediterranean Sea longline fisheries. Fisheries Res., 84, 233-246 (2007).

Edwards, M. and A.J. Richardson: Impact of climate change on marine pelagic phenology and trophic mismatch. Nature, 430, 881-884 (2004).

Faradonbe, M.Z. and S. Eagderi: Fish assemblages as influenced by environmental factors in Taleghan River (the Caspian Sea basin, Alborz Province, Iran). Caspian J. Env. Sci. 13, 363-371 (2015).

Faruque, H., D.A. Ahsan, M.H. Sarker and E.F. Gladun: Effect of Ganges River morphological dynamics and Farakka Barrage on upward migration and catch of Indian Shad (Tenualosa llisha) in Bangladesh. Tyumen State University Herald. Nat. Res. Use Ecol., 2,34-58 (2016).

George, B., J.I.N. Kumar and N.R. Kumar: Study on the influence of hydro-chemical parameters on phytoplankton distribution along Tapi estuarine area of Gulf of Khambhat, India. Egyptian J. Aquat. Res., 38, 157-170 (2012).

Haldar, G.C. and S.M. N. Amin: Population dynamics of male and female hilsa, Tenualosa ilisha of Bangladesh. Pakistan J. Biol. Sci., 8, 307$313(2005)$.

Haldar, G.C., M.A. Mazid, M.A. Rahman and S.M.N. Amin: The present status of Hilsha (Tenualusa ilisha) fishery in Bangladesh. In: Proceedings of the International Terubok Conference, Sarawak Development Institute (Eds.: S. Blaber, D. Brewer, D. Milton and C. Baino), Malaysia. pp. 52-64 (2001).

Hall-Spencer, J.M., R. Rodolfo-Metalpa, S. Martin, E. Ransome, E.M. Fine and S.M. Turner: Volcanic carbon dioxide vents show ecosystem effects of ocean acidification. Nature, 454 (7200), 96-99 (2008).

Hossain, M.S., S. Sarker, S.R. Chowdhury and S.M. Sharifuzzaman: Discovering spawning ground of hilsa shad (Tenualosa ilisha) in the coastal waters of Bangladesh. Ecol. Model., 282, 59-68 (2014).

Islam, M.S.: The life history and fishery of hilsa in Bangladesh and their implication for management. Fishbyte, 7, 3-4 (1989).

Jahan, I., D. Ahsan and M.H. Farque: Fishers' local knowledge on impact of climate change and anthropogenic interferences on Hilsa fishery in South Asia: Evidence from Bangladesh. Environ. Dev. Sustain., 19, 461-478 (2015).

Jefferson, T. A. and B.E. Curry: A global review of porpoise (Cetacea: Phocoenidae). Mortality in gillnets. Biol. Conser., 67, 167-183 (1994).

Kathiresan, K. and B. Bingham: Biology of mangroves and mangrove ecosystems. Adv. Marine Biol., 40, 81-215(2001).

Kibria, M.G. and K.K.U. Ahmed: Diversity of selective and non-selective fishing gear and their impact on inland fisheries in Bangladesh. NAGA, WorldFish Center Newsletter, 28, 43-48 (2005).

Maes, J., S. Van Damme, P. Meire and F. Ollevier: Statistical modeling of seasonal and environmental influences on the population dynamics of an estuarine fish community. Marine Biology, 145, 1033-1042 (2004).
Marais, J.F.K.: Some factors that influence fish abundance in South African estuaries. S. Afr. J. Mar. Sci., 6, 67-77 (1988).

Miah, M.S., M.A. Rahman, G.C. Haldar and M.A. Mazid: Some aspect of popula-tion dynamics of juvenile hilsa shad (Tenualosa ilisha Ham.) from the Meghna River, Bangladesh. Bangladesh J. Fish. Res., 4, 75-81 (2000).

Miah, M.S.: Climatic and anthropogenic factors changing spawning pattern and production zone of Hilsa fishery in the Bay of Bengal. Weather and Climate Extremes, 7, 109-115 (2015).

Montana, C.G., S.K. Choudhary, S. Dey and K.O. Winemiller: Compositional trends of fisheries in the River Ganges, India. Fisheries Manag, Ecol., 18, 282-296 (2011).

Morrill, J. C., R.C. Bales and M.H. Conklin: Estimating stream temperature from air temperature: Implications for future water quality. J. Environ. Eng.,131, 139-146 (2005).

Pramanik, M.M.H., M.A. Rahman, T. Ahmed, Flura and M.M. Hasan: Gill net selectivity of hilsa (Tenualosa ilisha) in the Meghna River Estuary of Bangladesh. J. Aquac. Res. Devel., 8, 483 (2017).

Rahman, M.A., G.C. Haldar, D.A. Milton, M.A. Mazid and M.S. Miah: A study on the population dynamics of hilsa, Tenualosa ilisha (Hamilton-Buchanan) in Bangladesh. Indian J. Animal Sci., 71, 4648 (2001).

Rahman, M.A., M.S. Miah, M.J. Rahman and G.C. Haldar: Jatka Juvenile hilsa, Tenualosa ilisha fishery in Bangladesh. Indian J. Fisheries, 42, 13-16 (1995).

Rahman, Z.R., M.A. Wahab and L.A. Choudhury: Hilsa and Hilsa Fishers: Exploring Conservation Livelihood Win-wins. Power and Participation Research Centre, Dhaka, Bangladesh (2014).

Rakowitz, G., B. Berger, J. Kubecka and H. Keckeis: Functional role of environmental stimuli for the spawning migration in Danube nase Chondrostoma nasus (L.). Ecology of Freshwater Fish, 17, 502-514 (2008).

Rashleigh, B.: Relation of environmental characteristics to fish assemblages in the upper French broad river basin, North Carolina. Environ. Monit. Assess., 93, 139-156 (2004).

Santos, A. and P. Miguel: Fisheries oceanography using satellite and airborne remote sensing methods: A review. Fish. Res., 49, 1-20 (2000).

Sharif, A.S.M., M.S. Islam, M.N. Hoque and M.S. Bhuyan: Spatial and temporal environmental effect of lower Meghna River and its estuary on phytoplankton, Bangladesh. Int. J. Fauna Biol. Studies, 4, 13-22 (2017a).

Sharif, A.S.M., S. Islam and M. Islam: Occurrence and distribution of macrobenthos in relation to physico-chemical parameters in the lower Meghna River estuary, Bangladesh. Int. J. Marine Sci., 7, 102-113 (2017b).

Siddique, A.B.: Country's $6^{\text {th }}$ Illish sanctuary coming soon. Dhaka Tribune (2015).

U.S. EPA: Ambient Aquatic Life Water Quality Criteria for Dissolved Oxygen (Saltwater): Cape Cod to Cape Hatteras. EPA-822/R00/012. Office of Water, Washington, DC. (2000).

Vega-Cendejas, M. E., M.H. De Santillana and S. Norris: Habitat characteristics and environmental parameters influencing fish assemblages of karstic pools in southern Mexico. Neotropical Ichthyology, 11, 859-870 (2013).

Whitfield, K. A.: Ichthyofaunal assemblages in estuaries: A South African case study. Revi. Fish Biol. Fisher., 9, 151-186 (1999).

Zhu, R., Q. Li, W. Wang, L. Chu and Y. Yan: Effects of local, river-network and catchment factors on fish assemblages in the headwater streams of the Xin'an basin, China. J. Freshwater Ecol., 32,1, 309322 (2017). 